\title{
THE USE OF LASER SCANNING AND UNMANNED AERIAL VEHICLES IN CONSTRUCTION SURVEYING IN THE LIGHT OF LEGAL REGULATIONS IN POLAND
}

\author{
Edyta Puniach a, *, Anita Kwartnik-Pruc ${ }^{\text {a }}$ \\ ${ }^{a}$ AGH University of Science and Technology, Faculty of Mining Surveying and Environmental Engineering, $30-059$ Krakow, \\ Poland, Al. Mickiewicza 30, 30-059 Kraków, Poland, E-mails:* epuniach@agh.edu.pl, akwart@agh.edu.pl
}

Received: 14.10.2018 / Accepted: 12.11.2018/ Revised: 20.11.2018 / Available online: 15.12.2018

DOI: $10.2478 /$ jaes-2018-0022

KEY WORDS: laser scanning, unmanned aerial vehicle (UAV), construction surveying.

\begin{abstract}
:
Construction surveying consist in overall surveying works performed at every stage of the construction and use of a building structure. The surveyor participates in the processes of designing, direct implementation, maintenance and use, as well as demolition of a building structure. Advanced surveying techniques, such as laser scanning and UAV photogrammetry, are being increasingly used to perform the surveyor's tasks. The aim of this research paper was to analyze the Polish legal regulations for the possibilities of applying the above-mentioned techniques to carry out the surveying works which are subject to the obligatory submission to public administration authorities. The primary focus was placed on the type of the works associated with construction surveying. The conducted research studies confirmed the lack of appropriate guidelines that would clearly define the scope and method of using laser scanning and UAV photogrammetry in construction surveying. At the same time, it was demonstrated that both these techniques of spatial data acquisition were sufficiently accurate to perform plane and vertical land surveys pursuant to the legal acts currently in force in Poland, and they can be used at selected stages of construction surveying. Finally, the authors proposed some solutions that would make it easier for the surveyors to use laser scanning and UAV photogrammetry in standard surveying works.
\end{abstract}

\section{INTRODUCTION}

\subsection{Construction surveying}

Construction surveying consist in overall surveying works performed during the implementation of all types of construction projects (Rozporządzenie, 1995). The surveyor is absolutely essential at every stage of the construction process, from the planning phase to the completion of the investment. There is a need to provide the investor with various types of surveying and cartographic studies (e.g. topographic or thematic maps), already at the stage of the initial studies and pre-project planning analyzes. The preparation of the investments should be preceded by the determination of the boundaries of the real property constituting the investment area (through surveying and legal processes related to construction surveying for real estate management). During the design phase, the surveyor is obliged to prepare a map for design purposes. If necessary, additional surveys are also performed, aimed e.g. at creating terrain cross-sections and profiles or digital terrain models (DTM). The construction starts when preparatory works are carried out on the construction site, which include the setting out of the structure in the field. At the construction phase, it is often necessary to render continuous surveying services for the erection and assembly of a building structure, as well as to carry out measurements of displacements and strains of the structure and its foundation. In order to complete the construction phase, the as-built map should be drawn up. It is a document that contains the information about the current spatial distribution of the elements of land development in the investment area. The as-built map is also one of the basic documents necessary for applying for an occupancy permit for a building structure. The surveyor is also obliged to assess the conformity of the erected building structure with the design. The surveyor's work does not finish at the end of the construction phase. The tasks also include continuous monitoring of displacements and operational strains to prevent possible construction disasters. The final stage in which the surveyor is involved is the demolition process, which requires the updating of the database of topographic objects, and of the base map as well.

All the works associated with construction surveying performed by the surveyor require field measurements. A wide range of surveying instruments is used for this purpose, including total stations, levelers or GNSS receivers, the use of which does not raise any doubts in the light of the Polish laws. However, laser scanners and unmanned aerial vehicles equipped with nonmetric cameras are used more and more frequently for field surveys. It has been proven numerous times that both these methods are very well suited to document various types of objects (Pritchard et al., 2017, Han et al., 2017, Ćwiąkała et al., 2018). Unfortunately, the Polish law is not precise in terms of their use in topographic surveys, the results of which are

\footnotetext{
* Corresponding author.
} 
submitted to the public administration bodies (the geodetic and cartographic documentation centers).

\subsection{Laser scanning}

Laser scanning is considered to be a relatively new technique of geospatial data acquisition, despite the fact that its history dates back to the 1990s. It is an active remote sensing system known as LIDAR (Light Detection and Ranging). The principle of operation of all laser scanners is similar and consists in measuring the distance between the field details and the device itself. Most frequently, the result of the scanning process is a point cloud. The product can be both the point cloud itself as the final product or its derivatives: visualizations, plans, maps, drawings, digital terrain models (DTM) or digital surface models (DSM). The term laser scanning has a very broad meaning. In surveying, three variants are usually used: aerial (ALS), mobile (MLS) and terrestrial (TLS) laser scanning, which are essentially different.

Terrestrial laser scanners allow capturing the data on relatively small, single objects (e.g. buildings, structures, and their complexes). For this purpose, a special optical system with a given frequency sends a measuring beam in a specific direction, which is reflected from an obstacle and received as well as recorded by the device. As a result, the coordinates of the points $\mathrm{X}, \mathrm{Y}, \mathrm{Z}$ are determined in the local layout of the scanner, which can be transformed to any geodetic coordinate system. Laser imaging can be performed irrespective of lighting conditions, because the device most often uses radiation from the nearinfrared range. Laser scanners are usually equipped with an optical sensor (built-in or external camera), which also allows to record the RGB components of each point (Shan, Toth, 2018).

In the case of ALS and MLS, the scanning device is mounted on a mobile platform (aircraft or vehicle). Therefore, in addition to the data recorded by the scanner, the information about the spatial position of the measuring instrument is saved. This is possible thanks to inertial (IMU) and satellite (GNSS) navigation (Vosselman, Maas, 2010). The mobile systems enable to perform efficient surveys of large areas (linear or surface), but in lower resolution and with lower accuracy than terrestrial scanners.

Laser scanning is a much more efficient method of spatial data acquisition than any other surveying techniques. It is unrivalled in measuring large spaces as well as complex structures, while ensuring high detail and accuracy of the measurement. A point cloud of the surveyed object, which is the starting material for further documentation, is quickly obtained. Laser scanning has brought a new standard of the data that is used e.g. in landscape monitoring (Hofierka et al., 2017), recording structures and processes relating to geomorphology or geology (Han et al., 2017, Goodwin et al., 2017), in architecture (Martíneza et al., 2012) or construction engineering (Yang et al., 2017, Lõhmus et al., 2018). The point clouds are used to create the $3 \mathrm{D}$ models of buildings (Balawejder et al., 2016) and even entire cities (Hron, Halounová, 2015). Laser scanning allows to develop comprehensive documentation with high accuracy and detail, at every stage of the building's life cycle. This technique also saves time and minimizes costs. The above-mentioned factors result from the increasing popularity of laser scanning, also in the field of creating and updating BIM models (Volk et al., 2014, Frykowska, Stachelek, 2018).

\subsection{Unmanned aerial vehicles}

The history of unmanned aerial vehicles, commonly referred to as "drones", is almost as long as of the manned aircraft. Nevertheless, the civilian market noticed the enormous potential of UAVs on a large scale not until the beginning of the $21 \mathrm{st}$ century. In recent years, the popularity of unmanned aerial vehicles has increased significantly. Currently, they are widely used in many areas of the economy, ranging from military, to broad civil applications - in forestry, agriculture and environmental protection (Torresan et al., 2017), archeology (Campana, 2017), construction (Eschmann et al., 2013, Ridolfi, 2017) and geodesy (Nex, Remondino, 2014).

UAVs can have various designs, shapes and sizes. There are many types of these devices, including: balloons, airships, gliders, kites, fixed wing gliders, propeller and jet engines, rotor-kites, single rotors (helicopters), coaxial rotors, quadrotors, multi-copters. In surveying, multi-copters and airships are most commonly used. Unmanned aerial vehicles can be equipped with a variety of sensors (cameras, thermal imaging cameras, multispectral cameras, LIDAR, SAR). Typical, and at the same time the cheapest, UAV applications are based on the images captured in the field of visible light.

Compared to other methods of spatial data acquisition, UAV photogrammetry can be appealing due to the portability of the required UAV platforms, the possibility of self-designing and modifying the integrated sensors, the availability of userfriendly software for data evaluation, the possibility to reach areas inaccessible with ground-based surveys and the relatively low cost. The market for photogrammetric imaging is inevitably heading towards full automation. It is expected that, in a few years, UAVs will be transformed into full-size robots, autonomous machines, with basic training being enough to control them and to analyze the data obtained by these devices. The UAV-based images are a rich material being the source of the spatial data. Typical products obtained from these data include: point clouds, models in the form of a grid of triangles or squares, or orthoimages. They are used to prepare cartographic documentation, to calculate the volume of earth masses, the analysis of displacements, modelling, etc. One of the most popular applications of UAVs is creating digital terrain models and orthophotomaps that can be used e.g. in construction surveying.

\section{CONSTRUCTION SURVEYING IN THE LIGHT OF POLISH LEGAL REGULATIONS}

The basic normative act regulating the work of land surveyors in Poland is the Geodetic and Cartographic Law (Ustawa, 1989). Pursuant to Article 11 (Ustawa, 1989), construction surveying works may be performed only by the entities conducting the economic activity, after the notification of such work to the relevant Geodetic and Cartographic Documentation Center. In Poland, immediately after the Second World War, it was decided that special centers would be established where the results of surveying works would be collected. As of today, there is a rich collection of these data called the national geodetic and cartographic resource. The national geodetic and cartographic resource is owned by the State and it is collected in geodetic and cartographic documentation centers - the district centers, the provincial centers and in the Main Center 
(Rozporządzenie, 2013), functioning as part of the public administration apparatus.

Construction surveys carried out in Poland are managed by the district geodetic and cartographic documentation centers. The cooperation between the surveyor and the center at the very beginning involves the surveyor notifying the center about the surveying works to be carried out, together with the determination of the scope of these works, and the acquisition of the data necessary to carry out the works from the geodetic and cartographic database (e.g. the coordinates of the geodetic control points, the base map or the cadastral map). Having finished the work, the surveyor is obliged to submit the complete documentation to the center to verify the correctness of its preparation. The results of correctly performed surveying or cartographic work are included in the resource, and the materials intended for the investor/principal - usually being the map - are marked with an appropriate clause that they were included in the resource.

Pursuant to $\$ 2$ section 1 of (Rozporządzenie, 1995), surveys and construction surveying can only be performed by the entities who hold the necessary professional qualifications in the field of geodesy and cartography. There are as many as seven levels of qualifications specified in art. 43 of the Geodetic and Cartographic Law (Ustawa, 1989):

1) plane and vertical land surveys, setting-out surveys and asbuilt surveys;

2) delimitation and subdivision of real estate (land) and preparation of the documentation for legal purposes;

3) planimetric surveys;

4) construction surveying;

5) surveying of farmlands and forests

6) mapping;

7) photogrammetry and remote sensing.

In order to be granted such qualifications, the surveyor must prove to have received proper education, long and varied professional practice, and in the case of the qualifications of levels 1, 2, 4 and 5, the surveyor must also pass the state exam (Ustawa, 1989, Rozporządzenie, 2014a). Two levels of the qualifications are directly related to construction surveying. Depending on the size and complexity of the investment, the surveyor is required to hold the level 1 qualifications - plane and vertical land surveys, setting-out surveys and as-built surveys, or the level 4 qualifications - construction surveying. In the case of using the UAV technology, a question arises of the necessity to hold the level 7 qualifications - photogrammetry and remote sensing.

Under the Regulation of the Minister of Interior and Administration of November 9, 2011 on technical standards of performance of plane and vertical land surveys as well as developing and submitting the results of these surveys to the national geodetic and cartographic resource (Rozporzadzenie, $2011 b$ ), in all geodetic works related to construction surveying, the geodetic measurements should be performed in a manner ensuring the appropriate accuracy of the location of the field detail in relation to the nearest points of the geodetic control, measurement control or setting-out control ( $\$ 51$ of Rozporządzenie, 2011b). Pursuant to $\$ 32$ of (Rozporządzenie 2011b), plane land surveys can be performed using the following methods:
1) the polar method,

2) the orthogonal method,

3) the intersections:

a) angular,

b) linear,

c) angular-linear,

4) precise positioning using GNSS.

The Regulation (Rozporządzenie, 2011b) distinguishes three groups of field details, different in terms of the accuracy requirements:

1) I group - field details unambiguously identifiable in the field, preserving the long-term invariability of shape and location, in particular:

a) boundary markers and boundary points,

b) survey markers,

c) building structures and facilities, including the elements of public utilities network, directly available for measurement,

\section{2) II group:}

a) field details unambiguously identifiable in the field, whose shape and location does not preserve the long-term invariability, in particular: buildings structures and earthen structures, such as embankments, excavations, dikes, dams, flood dikes, ditches, canals and artificial water reservoirs,

b) covered building structures and facilities, including covered elements of public utilities network,

c) land development elements, in particular: parks, lawns, playgrounds and recreation areas, green squares, single trees and sports grounds;

3) III group - field details whose unambiguous identification in the field is difficult and depends on the assessment of the person performing the survey, including:

a) land use contours and soil pits for the needs of soil classification,

b) watercourses and water reservoirs with natural shorelines,

c) forest divisions in forest areas and national parks.

The horizontal surveys should be performed in the manner ensuring the determination of the location of the topographic point relative to the nearest points of the horizontal control and the measurement control with an accuracy of not less than 0.10 $\mathrm{m}$ - for the field details of the first-order accuracy, and $0.30 \mathrm{~m}$ as well as $0.50 \mathrm{~m}$ - for the field details of the second- and thirdorder accuracy, respectively.

Pursuant to $\S 36$ of (Rozporządzenie, 2011b), the vertical land surveys can be performed using the following methods:

1) geometric levelling;

2) trigonometric levelling;

3) satellite levelling;

4) laser scanning.

However, there are slightly different accuracy requirements for the vertical land surveys. Pursuant to $\$ 37$ of (Rozporządzenie, 2011b), they should be performed in a manner ensuring the determination of the elevations of the topographic points relative to the nearest points of the vertical geodetic control and the vertical measurement control with an accuracy of not less than: 
1) $0.05 \mathrm{~m}$ - for building structures and facilities, as well as for the points marked in the field,

2) $0.02 \mathrm{~m}$ - for sewers and sewage devices,

3) $0.10 \mathrm{~m}$ - for earthen structures, elastic or electromagnetically measured underground utilities as well as points/sites unmarked in the field.

The basic cartographic documentation in the investment process comprises: the base map, the map for design purposes and the as-built map. Pursuant to art. 2 clause 7 of the Geodetic and Cartographic Law (Ustawa, 1989) - the base map is a largescale cartographic study containing the information on the spatial location of: geodetic control points, record parcels, buildings, land use contours, classification contours, utilities networks, building structures and facilities, as well as other topographic objects and selected descriptive information about these objects. The map for design purposes covers the investment area together with a 30 meter buffer zone around it. It is developed on the copy of the base map, which must be updated by the surveyor and completed with the elements required for the preparation of the construction design, as specified in (Rozporządzenie, 1995, Rozporządzenie, 2011b). The geodetic as-built survey is performed to determine the spatial data defining the location and shape of the erected building structures. It forms the basis for the preparation of the as-built map illustrating the location and shape of the building structures as well as the manner of land development after the construction process is completed. The base map is updated on this basis.

The base map is developed in accordance with the Regulation of the Minister of Administration and Digitization of November 2, 2015 on the database of topographic objects and the base map (Rozporządzenie, 2015), based on the relevant data sets contained in:

1) the database of the national register of the basic geodetic, gravimetric and magnetic controls - the PRPOG database,

2 ) the database of the register of land and buildings (real estate cadastre) - the EGiB database,

3) the database of the surveying records of the network of public utilities - the GESUT database,

4) the database of the state register of the boundaries and areas of territorial division of the country - the PRG database,

5) the database of the detailed geodetic controls - the BDSOG database,

6) the database of the topographic objects with the detail ensuring the development of standard cartographic documentation at the scales of 1:500 - 1:5000 - the BDOT500 database.

These databases have been established in Poland since 2013 (Balawejder, Adamczyk, Cygan, 2016) based on archival materials and they have been supplied and updated with the current results of the performed surveys. The target accuracy of the horizontal and vertical location of the field details is to be consistent with the requirements set out above and specified in (Rozporządzenie, 2011b). Such accuracy requirements also apply to all types of work related to construction surveying.

Surveying technique is of secondary importance, as in accordance with $\$ 15$ of (Rozporządzenie, 2011b), when performing plane and vertical land surveys, it is allowed to use the surveying methods, technologies and techniques other than those specified in the Regulation, provided that these methods, technologies and techniques ensure the acquisition of the observational data with the required accuracy, and at the same time, the contractor presents a description of these methods, technologies and techniques in the technical report, together with a mathematical analysis of the accuracy of the observational data. Such a formulated provision of law offers the possibility for the surveyor to apply modern techniques. However, in practice, due to the lack of detailed regulations, we encounter the problems of completing the documentation and specifying the qualifications of the surveyor who is to perform such work.

\section{LASER SCANNING IN THE LIGHT OF APPLICABLE POLISH REGULATIONS}

In the Polish law, laser scanning is defined as the method of imaging of the land surface, which consists in measuring the distance between an object covered by the measurement and a device (scanner) installed on an aircraft, a car, or a station, emitting and receiving laser pulses reflected from this object, with simultaneous determination of the spatial coordinates (X, $\mathrm{Y}, \mathrm{Z}$ ), defining the position of this device in space, and the direction of the laser beam at the moment of sending the pulse (Rozporządzenie, 2011b). Referring to both the principle of operation and the legal definition, a terrestrial laser scanner can be compared to a total station, however, the efficiency of capturing information by this instrument is unachievable for a total station, or even the most modern instruments, such as scanning total stations. On the other hand, total stations are ahead of laser scanners in terms of accuracy. Nevertheless, the accuracy of modern terrestrial laser scanners is very high (Table 1) and allows to generate the final products with an accuracy of even a few centimeters. This accuracy is affected by all stages of the measurement work. First of all, the errors related to field measurements should be taken into account (including scanner accuracy, laser spot diameter, instrumental errors, nature of the tested object and its environment, distribution of measurement stations). The next step involves taking account of the accuracy of the merging and orientation of the point clouds at the various positions of the scanner. The accuracy of the georeferencing process of the resulting point cloud (point cloud reference to the national coordinate system) and the accuracy of point cloud processing to generate the final product are also important issues (Soudarissanane et al., 2011; Lichti, Licht, 2006; Cosarca et al., 2009).

Table 1. Accuracy of selected terrestrial laser scanners (parameters specified by equipment manufacturers)

\begin{tabular}{|c|c|c|c|c|c|}
\hline Model & $\begin{array}{c}\text { Leica } \\
\text { ScanStation } \\
\text { P40 }\end{array}$ & $\begin{array}{c}\text { Riegl } \\
\text { VZ- } \\
400 i\end{array}$ & $\begin{array}{c}\mathrm{Z}+\mathrm{F} \\
\text { Imager } \\
5010 \mathrm{C}\end{array}$ & $\begin{array}{c}\text { Topcon } \\
\text { GLS- } \\
2000\end{array}$ & $\begin{array}{c}\text { Faro } \\
\text { Focus } \\
\text { S70 }\end{array}$ \\
\hline $\begin{array}{c}\text { Distance } \\
\text { measureme } \\
\text { nt accuracy }\end{array}$ & $\begin{array}{c}1,2 \mathrm{~mm}+ \\
10 \mathrm{ppm}\end{array}$ & $\begin{array}{c}5 \mathrm{~mm} \\
/ 100 \mathrm{~m}\end{array}$ & $\begin{array}{c}0,2 \mathrm{~mm} \\
/ 10 \mathrm{~m}\end{array}$ & $\begin{array}{l}3,5 \mathrm{~mm} \\
/ 150 \mathrm{~m}\end{array}$ & $\begin{array}{l}1 \mathrm{~mm} \\
/ 25 \mathrm{~m}\end{array}$ \\
\hline $\begin{array}{c}\text { Angle } \\
\text { determinati } \\
\text { on accuracy }\end{array}$ & $8 "$ & no data & $25,2 ”$ & $6 "$ & $19 "$ \\
\hline $\begin{array}{l}\text { 3D position } \\
\text { determinati } \\
\text { on accuracy }\end{array}$ & $\begin{array}{l}3 \mathrm{~mm} / \\
50 \mathrm{~m} \\
6 \mathrm{~mm} \\
/ 100 \mathrm{~m}\end{array}$ & $\begin{array}{c}5 \mathrm{~mm} \\
/ 100 \mathrm{~m}\end{array}$ & no data & no data & $\begin{array}{c}2 \mathrm{~mm} \\
/ 10 \mathrm{~m} \\
3,5 \mathrm{~mm} \\
/ 25 \mathrm{~m}\end{array}$ \\
\hline
\end{tabular}

* own study based on the technical specifications of laser scanners 
The principle of operation of aerial and mobile scanning systems is more complex and the achieved accuracy is lower. This is mainly associated with the lower accuracy of determining the spatial position of the scanner during the measurement performed in motion. Therefore, this research paper focuses primarily on terrestrial laser scanning.

Under the provisions of (Rozporządzenie, 2011b), laser scanning is a method that can be used for vertical land surveys (measuring the elevations of the points in the vertical system of the national reference frame, performed in the field). In the present case, TLS, MLS and ALS can be all used. The data captured by this method make it possible to update the database of topographic objects with the detail which allows the development of standard cartographic documentation on the topographic relief at the scales of 1:10,000 - 1:100,000. However, it should be noted that the topographic data which has been acquired should relate to the surface area, not its cover. Therefore, it is important to perform the correct filtration of the measurement data. In Poland, DTM was developed for the entire country based on the data from ALS. Such data, characterized by the point density from 4 to $12 \mathrm{pts} / \mathrm{m}^{2}$ and the mean elevation error of up to $0.2 \mathrm{~m}$, is made available by the Main Geodetic and Cartographic Documentation Center in Poland. These data, however, are not regularly updated and have accuracy which is too low to be used in construction surveying. They can be useful for preliminary studies and predesign analyzes, though.

Laser scanning is not mentioned in (Rozporzadzenie, 2011b) as the method used for the performance of the plane land surveys, i.e. the measurements enabling the identification and location of geometric centers of point objects, the turn points of the axes of linear objects and the turn points of the contours of surface objects, in a manner that allows determining the coordinates of these points in the binding system of rectangular coordinates, and determining the shape and type of these objects. Referring to the accuracy and detail of the product of laser scanning, i.e. the point cloud (Fig. 1), omitting laser scanning as a method allowing to perform direct plane land surveys, seems groundless, especially with regard to terrestrial laser scanning. This method is commonly used for mapping purposes. The research paper (Klapa, Mitka, 2017) proves that terrestrial laser scanning can be successfully used to develop and update the base map, and consequently, the map for design purposes. The authors have found that the cartographic materials based on the TLS point cloud are a reliable source of the information about land and the accuracy of determining the location of the various map contents has been estimated at 0.02-0.03 m. It has also been proven that TLS is accurate enough to update the database of the register of land and buildings (Kwartnik-Pruc, 2015). Terrestrial laser scanners are also commonly used in as-built surveys of the existing buildings, documentation of individual construction stages, as well as surveys of displacements of building structures and land (Mukupa et al., 2017, Yang et al., 2017, Medjkane et al., 2018). They are tools frequently used to create BIM models (Building Information Modeling), which are becoming increasingly popular, also in Poland (Volk et al 2014, Frykowska, Stachelek, 2018). The data collected by the laser scanning method are submitted to the investor. However, the same data are sporadically submitted to the geodetic and cartographic documentation centers as a result of the as-built surveys of the structure.
It should be noted that the legislator provided for the possibility of performing plane and vertical photogrammetric surveys using the laser scanning method. The photogrammetric survey is understood as a measurement of land or elevation, performed on a terrain model created from processed aerial or satellite images (Rozporządzenie, 2011b).

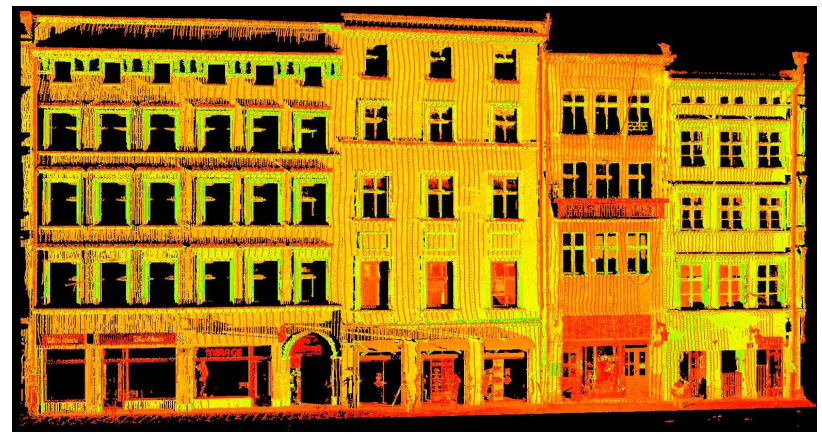

Figure 1. Point cloud as product of laser scanning

Another problematic issue relates to the professional qualifications that should be held by the surveyor who uses the laser scanning method to carry out surveying and cartographic work, including construction surveying. Pursuant to the requirements set out in (Rozporządzenie, 2014a) regarding the type and number of works as well as the surveying or cartographic studies necessary to acknowledge the professional practice, it should be stated that it is necessary to hold the level 7 qualifications - photogrammetry and remote sensing - in order to perform aerial laser scanning (Rozporządzenie, 2014a). Terrestrial laser scanning is not included in any scope of the professional practice of any of the qualifications. It should be added, that the broad term "laser scanning" is listed as one of the types of land surveys submitted to the geodetic and cartographic documentation centers (next to the works such as plane or vertical land surveys) (Rozporządzenie, 2014b).

Laser scanning has been the method used in land surveying for over 20 years. Nevertheless, Poland does not have strict legal regulations that would define the manner and scope of its use. This is a particularly big problem when using laser scanning to carry out geodetic and cartographic works subject to the obligatory submission to the geodetic and cartographic documentation centers, including the works related to construction surveying. In Poland, there is a sort of legal chaos in this respect, which results in the marginalization of laser scanning in plane and vertical land surveys. Although the method is frequently used to prepare the documentation for the investor, the results of such measurements are very rarely used to develop the documentation submitted to the geodetic and cartographic documentation centers.

\section{UAV-BASED PRODUCTS IN THE LIGHT OF APPLICABLE POLISH REGULATIONS}

The idea of using the UAVs in geodetic practice emerged in Poland already 10 years ago. Although the unmanned aerial vehicles are currently perceived as authorized measuring instruments, the Polish surveyors do not use them on regular basis. A survey conducted by the "Geodeta" monthly revealed that in 2016 , only $6 \%$ of the Polish surveying companies used unmanned aerial vehicles. It is worth noting that in the USA 
this index reached 38\% (Królikowski, 2017). One of the reasons for the relatively low interest in this technology in Poland are legal barriers, which limit the possibility of widespread use of this technology in surveying practice. The Aviation Law (Ustawa, 2002) quite clearly defines the rules and conditions for UAV flights in the Polish airspace. However, the problem is the Geodetic and Cartographic Law (Ustawa, 1989), which takes no notice of this technology at all.

The cheapest, and also the most popular solution based on the UAV technology are devices equipped with non-metric digital cameras. That is the reason why this research paper focuses on the UAV photogrammetry. It should be noted that, in accordance with the policy of the government, the Polish economy is to specialize in unmanned aerial vehicles, and the Polish market offers numerous devices dedicated for photogrammetric purposes. Their competitive prices and a wide range of software for the processing of the UAV-based images shall result in their increasing popularity in the surveying sector. The photogrammetric surveys performed using unmanned platforms require the photogrammetric mission to be planned in the first place. The photogrammetric mission plan is being prepared taking into account the specification of the surveying equipment used, the characteristics of the site, and the target GSD (ground sampling distance). It is also necessary to establish and measure ground control points (GCPs) for georeferencing purposes. After data acquisition, the images must be photogrammetrically processed. This stage includes automatic aerial triangulation with camera calibration. As a consequence, it is possible to generate a digital surface model (DSM) or digital terrain model (DTM), which will eventually allow the creation of orthoimages (Fig. 2), 3D models, or will be used for other studies. Figure 3 illustrates a general procedure for the development of the typical UAV-based photogrammetric products.

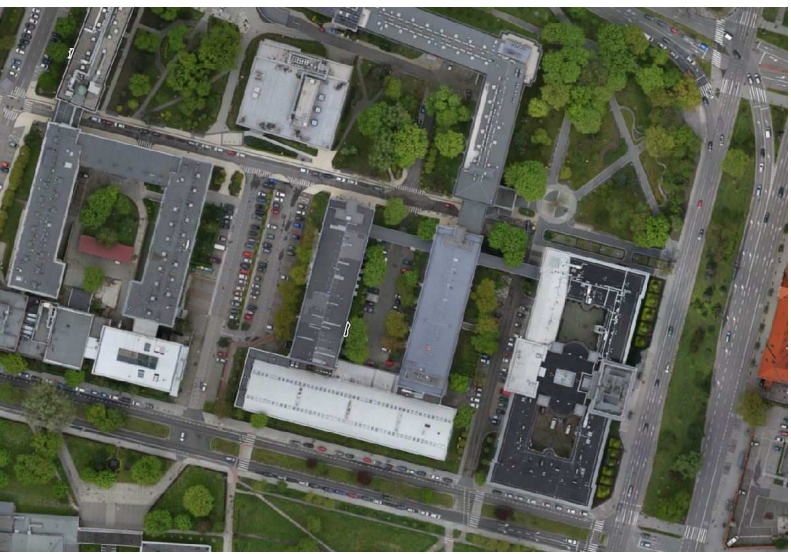

Figure 2. Orthoimages

In Poland, there are some regulations in force which govern the development of the UAV-based photogrammetric products (Rozporzadzenie, 2011a), but they relate to the data sets acquired from the aircraft or helicopters (presumably manned ones). These provisions had become binding before the UAVs started to be commonly used in surveying practice. Therefore, they are not adapted to the UAV-based photogrammetric products. Theoretically, based on the UAV-based images, the orthophotomap or DTM can be developed in accordance with the requirements specified in (Rozporządzenie 2011a). In practice, however, it is very difficult. It should also be noted that the orthophotomaps and digital terrain models are studies whose implementation should be submitted to the database of the Main Geodetic and Cartographic Documentation Center (Ustawa, 1989). When the imaging is commissioned by a nonpublic entity, these works are not subject to the obligatory notification, and the data does not have to be submitted to the Main Geodetic and Cartographic Documentation Center. However, the provisions do not regulate the issue of the development of the photogrammetric products for the purposes other than supplying the databases of the orthophotomap and of the digital terrain model (e.g. the works subject to notification to the County Geodetic and Cartographic Documentation Centers). Theoretically, this is not prohibited by law. Pursuant to (Rozporządzenie, 2011b), the photogrammetric surveys (the measurements conducted on the terrain model created from the processed aerial images) can be used for the performance of the plane and vertical surveys, while the cartometric surveys (the measurements conducted on the orthophotomap) - for the plane land surveys. Moreover, $\$ 15$ of the Regulation on technical standards of performance of plane and vertical land surveys as well as developing and submitting the results of these surveys to the national geodetic and cartographic resource (Rozporządzenie, 2011b) allows for the contractor to use any surveying technique for the performance of the work, as long as they prove that it complies with the accuracy requirements set out in the regulations. This is confirmed by numerous publications (Agüera-Vega, 2017, Benassi et al., 2017, Ćwiąkała et al., 2018, Puniach et al., 2018).

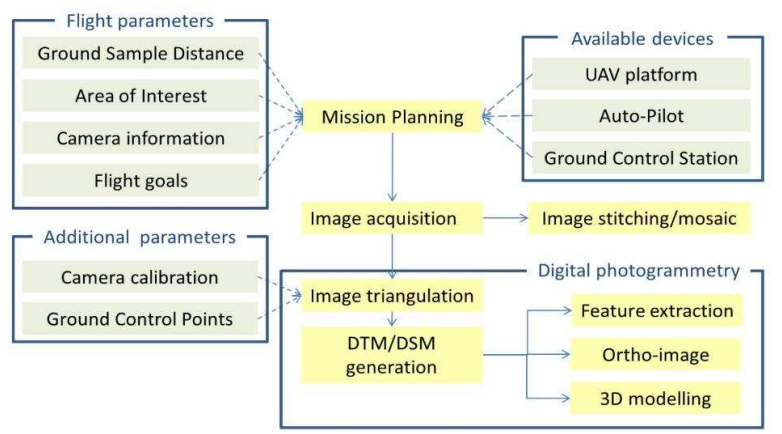

Figure 3. Scheme for development of typical UAV-based photogrammetric products (Nex, Remondino, 2014)

Today, UAV-based images are commonly used for mapping purposes. Their suitability for the development of cartographic studies for design purposes (Reinoso et al., 2017, Ajayi, 2018), as well as for the construction site 3D mapping (Vacanas et al., 2016, Álvares et al., 2018) has been confirmed. In the publication (Liu et al., 2014), it is claimed that unmanned aerial vehicles are an effective approach to obtain information from an additional view and bring significant benefits to civil engineering. UAVs are also used for the updating of the cadastral data (Puniach et al., 2018), for the surveys of building structures (Ridolfi et al., 2017) and the documentation of their damage (Eschmann et al., 2013). It seems natural that the orthophotomap developed on the UAV-based data can form the basis for the development of the map for design purposes with reference to the land management. UAVs can also be used for the as-built surveys of building structures. Such studies, as well as the documentation of individual construction stages, are currently being carried out and developed at the request of investors. The surveyors treat the UAV-based photogrammetric 
products as support materials. It is rarely the case that the same data is used to prepare the documents submitted to the database of the geodetic and cartographic documentation center. The reason is the lack of the guidelines on the use of UAVs to create orthophotomaps and DTMs, and to submit the results of these studies to the national geodetic and cartographic resource. On the other hand, it should be noted that the possibility of creating the UAV-based photogrammetric products is also limited as a result of the professional qualifications required in land surveying and cartography. It is usually necessary that the surveyor submitting the results of the surveys performed based on the UAV-based imaging to the geodetic and cartographic documentation center, had the level 7 professional qualifications (photogrammetry and remote sensing).

\section{RESULTS AND DISCUSSION}

The use of modern techniques in surveying is allowed pursuant to $\S 15$ of the Regulation on technical standards of performance of plane and vertical land surveys as well as developing and submitting the results of these surveys to the national geodetic and cartographic resource (Rozporządzenie, 2011b). This Regulation sets forth that when performing plane and vertical land surveys, it is allowed to use the methods, technologies and surveying techniques other than those specified in the Regulation, provided that these methods, technologies and techniques ensure that the observational data are captured with the required accuracy and, at the same time, the contractor provides a description of these methods, technologies and techniques, along with the mathematical analysis of the accuracy of the observational data, contained in the technical report.

Laser scanning has been mentioned in the above Regulation only as one of the surveying methods used for the performance of the vertical land surveys. This method has not been taken into account for the plane land surveys. It is true that the term "laser scanning" appears on the form used for submitting surveying works to the geodetic and cartographic documentation center (next to the types of works such as plane or vertical land surveys) (Rozporządzenie 2014b), but it is possible to distinguish between the terrestrial, mobile and aerial laser scanning, which differ greatly with the obtained accuracy of the position of field details and the size of the study. Failure to distinguish between various types of laser scanning techniques results in the discrepancies in the interpretation of the scope of competence of the geodetic and cartographic documentation centers, and makes it practically impossible to report this type of work or submit the data in the form of a point cloud to the center. Terrestrial laser scanning meets the accuracy requirements set out in (Rozporzadzenie 2011) regarding the acquisition of the plane and vertical data in construction surveying. Therefore, this particular method should be included in the catalogue of methods specified in the Regulation (Rozporządzenie, 2011b) with respect to the plane land surveys. This Regulation should also specify the method of submitting the spatial data acquired with this method to the geodetic and cartographic resource, because at present the geodetic and cartographic documentation centers refuse to accept the data in the form of a point cloud. Another issue that should be taken into account is including this technology in the catalogue of geodetic works required for the level 1 qualifications - plane and vertical land surveys, setting-out surveys and as-built surveys. More and more companies in Poland are in possession of terrestrial scanners and use this technology in geodetic surveys. This measurement method has its limitations, just like any other. Therefore, it is important that the surveyor who uses it for construction surveying had experience in planning and performing surveys with a terrestrial laser scanner, as well as the development of the results in the form of a point cloud.

The photogrammetric surveys performed using unmanned platforms are not included in the catalogue of surveying methods listed in (Rozporządzenie, 2011b). In Poland, there are some regulations in force which govern the development of the photogrammetric products (Rozporządzenie, 2011a), but they relate to the data sets acquired from the aircraft or helicopters (presumably manned ones). These provisions had become binding before the UAVs started to be commonly used in surveying practice and therefore they are not adapted to the UAV-based photogrammetric products. The use of technology is becoming increasingly popular in the field of surveying. The companies constructing drones and the software for processing the data acquired from UAVs are developing dynamically. Therefore, it is essential to prepare secondary legislation concerning this specific method in terms of its application in those surveying works, the performance of which has to be notified to the geodetic and cartographic documentation center. The final product must comply with the accuracy requirements for determining the location of the terrain detail set forth in (Rozporządzenie, 2011b). Thus, it should be provided for in these legal regulations that in construction surveying this particular method may constitute only a partial source of the data required to develop the map for design purposes or the asbuilt map. The second issue regarding the use of the UAV technology for construction surveying concerns the professional qualifications of the surveyor who renders services for the investment. All these works must be submitted to the district geodetic and cartographic documentation center by the surveyor who holds appropriate qualifications, and then the resulting materials are to be submitted to the geodetic and cartographic resource. In order to gain the level 7 qualifications photogrammetry and remote sensing, the surveyor must demonstrate the full spectrum of photogrammetric works performed from the board of the plane. The question that should be asked at this point is whether the surveyor developing an orthophotomap from the UAV-based data for a single building needs to have such an extensive experience? The software used to process the data acquired from the camera installed on the drone is largely doing it automatically. Of course, the surveyor must be able to correctly plan and properly perform the pass, plan and measure the photogrammetric control (ground control points), and to process the acquired data so that the results meet the accuracy requirements set out in (Rozporządzenie, 2011b). Therefore, it is worth considering dividing the level 7 qualifications into the works performed on large areas based on the data acquired from the board of the plane, and those carried out on small areas from the board of the drone.

\section{CONCLUSIONS}

The use of modern technologies in land surveying is an undeniable fact. Sooner or later, terrestrial laser scanners and UAVs will become as common as GNSS. Therefore, there is a need to adapt the existing legal regulations in Poland to the 
progress in the field of surveying techniques. First of all, these technologies should be included in the catalogue of permissible methods, and then the manner of submitting the survey results to the national geodetic and cartographic resource should be specified. The preparation of a new regulation on the implementation of photogrammetric surveys, or supplementation of the existing one with the UAV technology, together with the adjustment of the scope of the professional qualifications in this field of geodesy, should be considered.

\section{ACKNOWLEDGEMENTS}

The study has been carried out with financial support from the statutory research No 11.11.150.005 AGH University of Science and Technology in Krakow.

\section{References}

Agüera-Vega, F., Carvajal-Ramírez, F., Martínez-Carricondo, P., 2017. Assessment of photogrammetric mapping accuracy based on variation ground control point's number using unmanned aerial vehicle. Measurement, vol. 98, pp. 221-227. https://doi.org/10.1016/j.measurement.2016.12.002.

Ajayi, O.G., Palmer, M., Salubi, A.A., 2018. Modelling farmland topography for suitable site selection of dam construction using unmanned aerial vehicle (UAV) photogrammetry. Remote Sensing Applications: Society and Environment, vol. 11, pp. 220-230. https://doi.org/10.1016/j.rsase.2018.07.007.

Álvares, J.S., Costa, D.B., de Melo, R.R.S., 2018. Exploratory study of using unmanned aerial system imagery for construction site 3D mapping. Construction Innovation, vol. 18 Issue 3, pp. 301-320. https://doi.org/10.1108/CI-05-2017-0049.

Balawejder, M., Adamczyk, T., Cygan, M., 2016. The Problem of Adjusting Polish Spatial Information Resources to the Standards of the INSPIRE. In Proceedings of the GIS ODYSSEY 2016, Geographic Information Systems Conference and Exhibition, Perugia, Italy, 5-9 September 2016; pp. 14-24. http://gis.us.edu.pl/index.php/past-gis-conferences/23-gisodyssey-2016.

Balawejder, M., Warchoł, A., Matuła, P., Kret, M., 2016. Use technology LIDAR in passive documentation of historical sites. Use and Protection of Land Rasources: Actual Issues of the Science and Practice, p.97-100, Lviv, УДК 332.33, ББК 65.9 (4Укр)32-51я54,В-43.

http://www.Inau.lviv.ua//nau/attachments/3665_Konf_LNAU_1 8.05.2016.pdf\#page $=97$.

Benassi, F., Dall'Asta, E., Diotri, F., Forlani, G., Morra di Cella, U., Roncella, R., Santise, M., 2017. Testing Accuracy and Repeatability of UAV Blocks Oriented with GNSSSupported Aerial Triangulation. Remote Sens., vol. 9, 172. https://doi.org/10.3390/rs9020172.

Campana, S., 2017. Drones in Archaeology. State-of-the-art and Future Perspectives. Archaeol. Prospect., vol. 24, pp. 275-296. https://doi.org/10.1002/arp.1569.
Cosarca, C., Jocea, A. and Savu, A., 2009. Analysis of error sources in Terrestrial Laser Scanning. RevCAD Journal of Geodesy and Cadaster, vol. 9, pp. 115-124.

Ćwiąkała, P., Kocierz, R., Puniach, E., Nędzka, M., Mamczarz, K., Niewiem, W., Wiącek, P., 2018. Assessment of the Possibility of Using Unmanned Aerial Vehicles (UAVs) for the Documentation of Hiking Trails in Alpine Areas. Sensors, vol. 18, no. 1, 81. https://doi.org/10.3390/s18010081.

Ćwiąkała, P., Puniach, E., Wdowiak, P., 2018. Optimisation of the UAV-based photogrammetric data collection process in documentation of linear objects of substantial height differences. Geographic Information Systems Conference and Exhibition "GIS ODYSSEY 2018" Perugia, Italy, Conference proceedings, pp. 146-156. http://www.gis.us.edu.pl/index.php/conference-proceedings2018.

Eschmann, C., Kuo, C.-M., Kuo, C.-H., Boller, C., 2013. HighResolution Multisensor Infrastructure Inspection with Unmanned Aircraft Systems. International Archives of the Photogrammetry, Remote Sensing and Spatial Information Sciences, vol. XL-1/W2, 125-129. DOI: 0.5194/isprsarchivesXL-1-W2-125-2013.

Frykowska, A., Stachelek, J., 2018. A no-reference method of geometric content quality analysis of 3D models generated from laser scanning point clouds for hBIM. Journal of Cultural Heritage (available online 19 April 2018). https://doi.org/10.1016/j.culher.2018.04.003.

Goodwin, N.R., Armston, J.D., Muir, J., Stiller, I., 2017. Monitoring gully change: A comparison of airborne and terrestrial laser scanning using a case study from Aratula, Queensland. Geomorphology, vol. 282, 195-208. https://doi.org/10.1016/j.geomorph.2017.01.001.

Han, J.Y., Huang, N.J., Chuang, J.T.Y., 2017. Application of laser scanning for rapid geologic documentation of trench exposures. Engineering Geology, vol. 224, 97-104. https://doi.org/10.1016/j.enggeo.2017.05.010.

Hofierka, J., Gallay, M., Kaňuk, J., Šašak, J., 2017. Modelling Karst Landscape with Massive Airborne and Terrestrial Laser Scanning Data. In: Ivan, I., Singleton, A., Horák, J., Inspektor, T. (Eds.), The Rise of Big Spatial Data. Lecture Notes in Geoinformation and Cartography. Springer, Cham, pp. 141-154. https://doi.org/10.1007/978-3-319-45123-7_11.

Hron, V., Halounová, L., 2015. Automatic Generation of 3D Building Models from Point Clouds. In: Ivan I., Benenson I., Jiang B., Horák J., Haworth J., Inspektor T. (Eds), Geoinformatics for Intelligent Transportation. Lecture Notes in Geoinformation and Cartography. Springer, Cham. https://doi.org/10.1007/978-3-319-11463-7_8.

Klapa, P., Mitka, B., 2017. Application of terrestrial laser scanning to the development and updating of the base map. Geodesy and Cartography, vol. 66, no. 1, 2017, 59-72. DOI: 10.1515/geocart-2017-0002.

Królikowski, J., 2017. Skrzydlaty pomocnik. Przegląd bezzałogowych płatowców do celów geodezyjnych (Winged 
assistant. Overview of unmanned aerial vehicles for surveying purposes). Geodeta, vol. 1, no. 265, p. 20.

Kwartnik-Pruc, A., 2015. Possibilities of using innovative sources of information on real estate in the spatial data collection process. Real Estate Management and Valuation, vol. 23, no. 1, pp. 103-113. https://doi.org/10.1515/remav2015-0010.

Lichti, D.D.,Licht, M.G., 2006. Experiences with terrestrial laser scanner modelling and accuracy assessment. The International Archives of the Photogrammetry, Remote Sensing and Spatial Information Sciences, vol. XXXVI, no. 5, pp. 155-160.

Liu, P., Chen, A.Y., Huang, Y.-N., Han, J.-Y., Lai, J.-S., Kang, S.-C., Wu, T.-H., Wen, M.-C., Tsai. M.-H., 2014. A review of rotorcraft Unmanned Aerial Vehicle (UAV) developments and applications in civil engineering. Smart Structures and Systems, vol. 13, no. 6, 1065-1094. http://dx.doi.org/10.12989/sss.2014.13.6.1065.

Lõhmus, H., Ellmann, A., Märdla, S., Idnurm, S., 2018. Terrestrial laser scanning for the monitoring of bridge load tests - two case studies. Survey Review, vol. 50, no. 360, pp. 270-284. 10.1080/00396265.2016.1266117.

Martíneza, J., Soria-Medinab, A., Ariasa, P., Buffara-Antunes, A.F., 2012. Automatic processing of Terrestrial Laser Scanning data of building façades. Automation in Construction, vol. 22, pp. 298-305. https://doi.org/10.1016/j.autcon.2011.09.005.

Medjkane, M., Maquaire, O., Costa, S., Roulland, T., Letortu, P., Fauchard, C., Antoine, R., Davidson, R., 2018. Highresolution monitoring of complex coastal morphology changes: cross-efficiency of SfM and TLS-based survey (Vaches-Noires cliffs, Normandy, France). Landslides, vol. 15, no. 6, pp. 10971108. https://doi.org/10.1007/s10346-017-0942-4.

Mukupa, W., Roberts, G. W., Hancock, C. M., Al-Manasir, K., 2017. A review of the use of terrestrial laser scanning application for change detection and deformation monitoring of structures. Survey Review, vol. 49, no. 353, pp. 99-116. 10.1080/00396265.2015.1133039.

Nex F., Remondino F. (2014). UAV for 3D mapping applications: a review. Applied Geomatics, vol. 6, no. 1, pp. 1-15. https://doi.org/10.1007/s12518-013-0120-x.

Pritchard, D., Sperner, J., Hoepner, S., Tenschert, R., 2017. Terrestrial laser scanning for heritage conservation: the Cologne Cathedral documentation project. ISPRS Annals of the Photogrammetry, Remote Sensing and Spatial Information Sciences, vol. IV-2/W2, pp. 213-220.

Puniach, E., Ćwiąkała, P. Dec, H., 2018. Impact of Ground Control Points (GCPs) distribution and unmanned aerial vehicle (UAV) flight parameters on accuracy of Digital Surface Model (DSM). Geographic Information Systems Conference and Exhibition "GIS ODYSSEY 2018" Conference proceedings, p. 387-396, from http://www.gis.us.edu.pl/index.php/conferenceproceedings-2018, accessed on 2018-10-04.
Puniach, E., Bieda, A., Ćwiąkała, P., Kwartnik-Pruc, A., Parzych, P., 2018. Use of Unmanned Aerial Vehicles (UAVs) for updating farmland cadastral data in areas subject to landslides. ISPRS Int. J. Geo-Inf., vol. 7, 331. https://doi.org/10.3390/ijgi7080331.

Reinoso, J.F., Gonçalves, J.E., Pereira, C., Bleninger, T., 2018. Cartography for Civil Engineering Projects: Photogrammetry Supported by Unmanned Aerial Vehicles. Iranian Journal of Science and Technology, Transactions of Civil Engineering, vol. 42, no. 1, pp. 91-96. https://doi.org/10.1007/s40996-0170076-x.

Ridolfi, E., Buffi, G., Venturi, S., Manciola, P., 2017. Accuracy Analysis of a Dam Model from Drone Surveys. Sensors, vol. 17, 1777. https://doi.org/10.3390/s17081777.

Rozporządzenie Ministra Gospodarki Przestrzennej i Budownictwa $\mathrm{z}$ dnia 21 lutego 1995 r. w sprawie rodzaju i zakresu opracowań geodezyjno-kartograficznych oraz czynności geodezyjnych obowiązujących w budownictwie (Regulation of the Minister of Spatial Economy and Construction of 21 February 1995 on the type and scope of geodetic and cartographic documentation, as well as surveying activities in force in the field of construction) (Journal of Laws no. 25 item. 133), from http://prawo.sejm.gov.pl/isap.nsf/DocDetails.xsp?id=wdu19950 250133, accessed on 2018-08-26.

Rozporządzenie Ministra Spraw Wewnętrznych i Administracji z dnia 3 listopada 2011(a) r. w sprawie baz danych dotyczących zobrazowań lotniczych i satelitarnych oraz ortofotomapy i numerycznego modelu terenu (Regulation of the Minister of Interior and Administration of November 3, 2011(a) on databases regarding aerial and satellite imaging and orthophotomap and Digital Terrain Model) (Journal of Laws 2011 no. 263 item 1571), from http://prawo.sejm.gov.pl/isap.nsf/DocDetails.xsp?id=WDU2011 2631571, accessed on 2018-08-26.

Rozporządzenie Ministra Spraw Wewnętrznych i Administracji z dnia 9 listopada 2011(b) r. w sprawie standardów technicznych wykonywania geodezyjnych pomiarów sytuacyjnych i wysokościowych oraz opracowywania i przekazywania wyników tych pomiarów do państwowego zasobu geodezyjnego i kartograficznego (Regulation of the Minister of Interior and Administration of November 9, 2011(b) on technical standards of performance of plane and vertical land surveys as well as developing and submitting the results of these surveys to the national geodetic and cartographic resource) (Journal of Laws 2011 no. 263 item 1572), from http://prawo.sejm.gov.pl/isap.nsf/DocDetails.xsp?id=WDU2011 2631572, accessed on 2018-08-26.

Rozporządzenie Ministra Administracji i Cyfryzacji z dnia 5 września 2013 r. w sprawie organizacji i trybu prowadzenia Państwowego Zasobu Geodezyjnego i Kartograficznego (Regulation of the Minister of Administration and Digitization Regulation of the Minister of Administration and Digitization of September 5, 2013 on the organization and the mode of conducting the national geodetic and cartographic resource) (Journal of Laws 2013 item 1183), from http://prawo.sejm.gov.pl/isap.nsf/DocDetails.xsp?id=WDU2013 0001183, accessed on 2018-08-26. 
Rozporządzenie Ministra Administracji i Cyfryzacji z dnia 31 stycznia 2014(a) r. w sprawie uprawnień zawodowych w dziedzinie geodezji i kartografii (Regulation of the Ministry of Administration and Digitization of January 31, 2014(a) on the qualifications in the field of geodesy and cartography (Journal of Laws 2014 item 176), from http://prawo.sejm.gov.pl/isap.nsf/DocDetails.xsp?id=WDU2014 0000176, accessed on 2018-08-26.

Rozporządzenie Ministra Administracji i Cyfryzacji z dnia 8 lipca 2014(b) r. w sprawie formularzy dotyczących zgłaszania prac geodezyjnych i prac kartograficznych, zawiadomienia o wykonaniu tych prac oraz przekazywania ich wyników do państwowego zasobu geodezyjnego i kartograficznego (Regulation of the Minister of Administration and Digitization of July 8, 2014(b) on forms for reporting of surveying and cartographic works, the notice of completion of the works and transfer of their results to the national geodetic and cartographic resource) (Journal of Laws 2014 item 924), from http://prawo.sejm.gov.pl/isap.nsf/DocDetails.xsp?id=WDU2014 0000924, accessed on 2018-08-26.

Rozporządzenie Ministra Administracji i Cyfryzacji z dnia 2 listopada 2015 r. $\quad$ w sprawie bazy danych obiektów topograficznych oraz mapy zasadniczej (Regulation of the Minister of Administration and Digitization of November 2, 2015 on the database of topographic objects and the base map) (Journal of Laws 2015 item 2028) from http://prawo.sejm.gov.pl/isap.nsf/DocDetails.xsp?id=WDU2015 0002028, accessed on 2018-08-26.

Shan, J., Toth, C.K., 2018. Topographic Laser Ranging and Scanning: Principles and Processing, Second Edition. Taylor \& Francis, CRC Press, Boca Raton.

Soudarissanane, S., Lindenbergh, R., Menenti, M., Teunissen, P., 2011. Scanning geometry: Influencing factor on the quality of terrestrial laser scanning points. ISPRS Journal of Photogrammetry and Remote Sensing, vol. 66, no. 4, pp. 389399. http://dx.doi.org/10.1016/j.isprsjprs.2011.01.005.

Torresan, C., Berton, A., Carotenuto, F., Di Gennaro, S.F., Gioli, B., Matese, A., Miglietta, F., Vagnoli, C., Zaldei, Z., Wallace, L., 2017. Forestry applications of UAVs in Europe: a review. International Journal of Remote Sensing, vol. 38, no. 810, pp. 2427-2447. DOI: 10.1080/01431161.2016.1252477.

Ustawa z dnia 17 maja 1989 r. Prawo geodezyjne i kartograficzne (Geodetic and Cartographic Law) (Journal of Laws 2017 item 2101 as amended), from http://prawo.sejm.gov.pl/isap.nsf/DocDetails.xsp?id=WDU2017 0002101, accessed on 2018-08-26.

Ustawa z dnia 3 lipca 2002 r. Prawo lotnicze (The Aviation Law) (Journal of Laws 2018 item 1183 as amended), from http://prawo.sejm.gov.pl/isap.nsf/DocDetails.xsp?id=WDU2002 1301112, accessed on 2018-08-26.

Vacanas, Y., Themistocleous, K., Agapiou, A., Hadjimitsis, D., 2016. The combined use of Building Information Modelling (BIM) and Unmanned Aerial Vehicle (UAV) technologies for the 3D illustration of the progress of works in infrastructure construction projects. Fourth International Conference on Remote Sensing and Geoinformation of the Environment,
Paphos, Cyprus, Proceedings Volume 9688. https://doi.org/10.1117/12.2252605.

Volk, R., Stengel, J., Schultmann, F., 2014. Building Information Modeling (BIM) for existing buildings Literature review and future needs. Automation in Construction, vol. 38, 109-127. https://doi.org/10.1016/j.autcon.2013.10.023.

Vosselman, G., Maas, H.-G., 2010. Airborne and Terrestrial Laser Scanning. Taylor \& Francis, CRC Press, Boca Raton.

Yang, H., Xu, X., Xu, W., Neumann, I., 2017. Terrestrial Laser Scanning-Based Deformation Analysis for Arch and Beam Structures. IEEE Sensors Journal, vol. 17, no. 14, pp. 46054611. DOI: 10.1109/JSEN.2017.2709908. 